Original article / Оригинальная статья

УДК 541.49; 542.06

DOI: https://doi.org/10.21285/2227-2925-2020-10-2-180-187

\title{
Synthesis and structure of sodium 1-alkoxy-1,4-dioxo-2-alkenolates and bis-(4-alkyl(aryl)- 1-oxo-1-alkoxyalkane-2,4-dionato) metals (II) based on them
}

\author{
(C) Elena A. Kunavina*, Sergey A. Peshkov*, Aybek Yu. Iskandarov** \\ ${ }^{*}$ Orenburg State University, Orenburg, Russian Federation \\ **Tashkent State Pedagogical University, Tashkent, Uzbekistan
}

\begin{abstract}
A priority task in contemporary organic chemistry consists in the synthesis of practically useful metal complexes having carbonyl-containing ligands. The present article details the isolation of several new bis-(4-alkyl(aryl)-1-oxo-1-alkoxyalkane-2,4-dionato) metals (II) via complex formation of metal salts of (zinc (II), copper (II) and nickel (II)) with sodium 1-alkoxy-1,4-dioxo-2-alkenolates obtained by condensation of alkyl (aryl) methyl ketones with dialkyl oxalates in the presence of sodium or sodium hydride as a condensing reagent. The structure of the synthesised sodium oxoenolates and metal complexes was confirmed by spectral analysis methods (IR, NMR ${ }^{1} H$-, NMR ${ }^{13} \mathrm{C}$-spectroscopy and mass spectrometry). In the IR spectra of the solid samples of the isolated compounds, stretching vibrations bands of ester carbonyl groups were identified, as well as high-intensity ether bands due to the vibrations of C-O-C bonds. For compounds containing aromatic fragments, bands corresponding to vibrations of monosubstituted benzene rings were found in the IR spectra. The NMR spectra of ${ }^{1} \mathrm{H}$ of sodium oxoenolates and metal complexes recorded in $D M S O-d_{6}$ demonstrated characteristic signals of ethoxy and n-butoxy fragments, methine protons, as well as protons of aromatic rings. Chemical shifts of carbon atoms in the NMR spectra ${ }^{13} \mathrm{C}$ of sodium oxoenolates correspond well to the reference values. In the mass spectra of synthesised compounds recorded in electrospray mode, signals of protonated and cationised molecules were observed $[\mathrm{M}+\mathrm{H}]^{+},\left[\mathrm{M}+\mathrm{NH}_{4}\right]^{+},[\mathrm{M}+\mathrm{Na}]^{+}$, $[\mathrm{M}+\mathrm{KI}]^{+}$. Using quantum chemical methods, the models of the obtained compounds were constructed along with a calculation of the formation energies and dissociation constants. Optimisation of the geometric parameters of the equilibrium states of sodium oxoenolate and metal complexes was carried out using the following two methods: density functional theory (DFT) and self-consistent field (SCF). The relative formation energies indicate high stability of the synthesised substances, while, according to the data obtained, copper complexes are characterised by greater stability in the gas phase as compared to zinc and nickel.
\end{abstract}

Keywords: sodium oxoenolates, metal complexes, synthesis, spectral analysis

Information about the article: Received January 23, 2020; accepted for publication May 29, 2020; available online June 30, 2020.

For citation: Kunavina EA, Peshkov SA, Iskandarov AYu. Synthesis and structure of sodium 1-alkoxy-1,4dioxo-2-alkenolates and bis-(4-alkyl(aryl)-1-oxo-1-alkoxyalkane-2,4-dionato) metals (II) based on them. Izvestiya Vuzov. Prikladnaya Khimiya $i$ Biotekhnologiya $=$ Proceedings of Universities. Applied Chemistry and Biotechnology. 2020;10(2):180-187. (In English) https://doi.org/10.21285/2227-2925-2020-10-2-180-187

\section{Синтез и строение 1-алкокси-1,4-диоксо-2- алкенолятов натрия и бис-(4-алкил(арил)-1-оксо- 1-алкоксиалкан-2,4-дионато)металлов(II)}

\section{на их основе}

\author{
Е.А. Кунавина*, С.А. Пешков*, А.Ю. Искандаров** \\ *Оренбургский государственный университет, \\ г. Оренбург, Российская Федерация \\ **Ташкентский государственный педагогический университет, \\ г. Ташкент, Узбекистан
}


Резюме: Синтез практически значимых металлокомплексов с карбонилсодержащими лигандами является приоритетной задачей современной органической химии. Комплексообразованием 1-алкокси-1,4-диоксо-2-алкенолятов натрия, полученных конденсацией алкил(арил)метилкетонов с диалкилоксалатами в присутствии в качестве конденсирующего реагента натрия или гидрида натрия, с солями металлов (цинка(II), меди(II) и никеля(II)) выделены новые бис-(4-алкил(арил)-1оксо-1-алкоксиалкан-2,4-дионато)металлы(II). Строение синтезированных оксоенолятов натрия u металлокомплексов подтверждено спектральными методами анализа (ИК-, ЯМР ${ }^{1} \mathrm{H}$-, ЯМР ${ }^{13}$ С-спектроскопии и масс-спектрометрии). В ИК-спектрах твердых образцов выделенных соединений обнаружены полосы валентных колебаний сложноэфирных карбонильных групп, а также эфрирные полосы высокой интенсивности, обусловленные колебаниями связей С-О-С. Для соединений, содержащих ароматические фррагменты в ИК-спектрах, найдены полосы, отвечающие колебаниям монозамещенных бензольных колец. В спектрах ЯMP ${ }^{1} \mathrm{H}$ оксоенолятов натрия и металло-комплексов, записанных в ДМСО- $d_{6}$, присутствуют классические сигналы этокси- $u$ н-бутоксифрагментов, метиновых протонов, а также протонов ароматических колец. Химические сдвиги углеродных атомов в спектрах ЯМР ${ }^{13} \mathrm{C}$ окоенолятов натрия хорошо сопоставимы со справочными значениями. В масс-спектрах синтезированных соединений, зарегистрированных 8 режиме электрораспыления, наблюдаются сигналы протонированных и катионированных молекул $[\mathrm{M}+\mathrm{H}]^{+},\left[\mathrm{M}+\mathrm{NH}_{4}\right]^{+},[\mathrm{M}+\mathrm{Na}]^{+},[\mathrm{M}+\mathrm{K}]^{+}$. C использованием квантово-химических методов построены модели полученных соединений и рассчитаны энергии образования и константы диссоциации. Оптимизация геометрических параметров равновесных состояний оксоенолятов натрия и металлокомплексов произведена в рамках двух методов: теории функционала плотности (DFT) и самосогласованного поля (SCF). Относительные величины энергий образования свидетельствуют о высокой стабильности синтезированных веществ, при этом, согласно полученным данным, больщей устойчивостью в газовой фразе характеризуются медные комплексы.

Ключевые слова: оксоеноляты натрия, металлокомплексы, синтез, спектральный анализ

Информация о статье: Дата поступления 23 января 2020 е.; дата принятия к печати 29 мая 2020 2.; дата онлайн-размещения 30 июня 2020 г.

Для цитирования: Кунавина Е.А., Пешков С.А., Искандаров А.Ю. Синтез и строение 1-алкокси-1,4диоксо-2-алкенолятов натрия и бис-(4-алкил(арил)-1-оксо-1-алкоксиалкан-2,4-дионато)металлов(II) на их основе. Известия вузов. Прикладная химия и биотехнология. 2020. Т. 10. N 2. С. 180-187. https://doi.org/10.21285/2227-2925-2020-10-2-180-187

\section{INTRODUCTION}

The chemistry of metal complexes is an extensive and rapidly developing field due to the multifunctionality and practical significance of these materials. Among the interesting properties of metal-complex compounds are included biological, pharmacological, photochemical and photophysical attributes [1-15]. Additional some metal complexes have been successfully used in the development of novel nanoscale structures [16]. Among metal complexes having organic ligands, the least studied are those based on polycarbonyl systems with conjugated $\alpha$ - and $\beta$-dioxo links. In order to expand the number of available metal complexes having carbonyl-containing ligands, the present study set out to synthesise new representative compounds and evaluate their stability using quantum chemical methods.

\section{EXPERIMENTAL}

Synthesis of 4-alkyl(aryl)-1-alkoxy-1,4-dioxo2-sodium alkenolates (1). General procedure. $0.58 \mathrm{~g}(25 \mathrm{mmol})$ of sodium was gradually added with stirring to a mixture of $25 \mathrm{mmol}$ of the corresponding methyl ketones (3-methylbutanone-2 or acetophenone), $25 \mathrm{mmol}$ of dialkyl oxalates (di-n-butyloxalate or diethyl oxalate) and
$50-100 \mathrm{ml}$ of benzene or toluene. The reagent mixture was boiled for 1.5-2 $\mathrm{h}$ (TLC control) in a round bottom flask with reflux condenser. Following evaporation of solvent, the obtained oxoenolates were washed with ether.

1-Butoxy-5-methyl-1,4-dioxo-2-hexene-2-sodium-olate $(\mathbf{1 a})$. Yield $84 \%$, melting point $\left(t_{\text {melt }}\right)-$ 118-122 ${ }^{\circ} \mathrm{C}$. IR spectrum, $v, \mathrm{~cm}^{-1}: 2959 v_{\text {as }}\left(\mathrm{CH}_{3}\right)$, $2931 v_{\text {as }}\left(\mathrm{CH}_{2}\right), 1698\left(\mathrm{C}^{1}=\mathrm{O}\right), 1625\left(\mathrm{C}^{4}=\mathrm{O}, \mathrm{C}=\mathrm{C}\right)$, $1379 \delta\left(\mathrm{CH}_{3}\right), 1267 \vee(\mathrm{C}-\mathrm{O}-\mathrm{C})$ 951, $770 \delta(\mathrm{CH})$. NMR spectrum ${ }^{1} \mathrm{H}, \delta$, ppm (DMSO- $\left.\mathrm{d}_{6}\right): 0,91 \mathrm{t}(3 \mathrm{H}$, $\left.\mathrm{O}\left(\mathrm{CH}_{2}\right)_{3} \mathrm{CH}_{3}, \mathrm{~J}_{\mathrm{HH}} 7,7 \mathrm{~Hz}\right), 0,98 \mathrm{~d}\left(6 \mathrm{H},\left(\mathrm{CH}_{3}\right)_{2} \mathrm{CH}\right)$, $1,35 \mathrm{~m}\left(2 \mathrm{H}, \mathrm{OCH}_{2} \mathrm{CH}_{2} \mathrm{CH}_{2} \mathrm{CH}_{3}\right), 1,60 \mathrm{~m}(2 \mathrm{H}$, $\left.\mathrm{OCH}_{2} \mathrm{CH}_{2} \mathrm{CH}_{2} \mathrm{CH}_{3}\right), 2,40 \mathrm{~m}\left(1 \mathrm{H},\left(\mathrm{CH}_{3}\right)_{2} \mathrm{CH}\right), 4,05 \mathrm{t}$ $\left(4 \mathrm{H}, 2 \mathrm{OCH}_{2} \mathrm{CH}_{2} \mathrm{CH}_{2} \mathrm{CH}_{3}, J_{\mathrm{HH}} 7,2 \mathrm{~Hz}\right), 5,65 \mathrm{~s}(1 \mathrm{H}$, $\mathrm{CH})$. NMR spectrum ${ }^{13} \mathrm{C}, \delta_{\mathrm{c}}$, ppm (DMSO-d $\left.\mathrm{d}_{6}\right): 13,5$ $\left(\mathrm{OCH}_{2} \mathrm{CH}_{2} \mathrm{CH}_{2} \mathrm{CH}_{3}\right), 18,6\left(\mathrm{OCH}_{2} \mathrm{CH}_{2} \mathrm{CH}_{2} \mathrm{CH}_{3}\right), 19,8$ $\left.\left.\left(\mathrm{CH}_{3}\right)_{2} \mathrm{CH}\right), 20,0\left(\mathrm{OCH}_{2} \mathrm{CH}_{2} \mathrm{CH}_{2} \mathrm{CH}_{3}\right), 30,1\left(\mathrm{CH}_{3}\right)_{2} \mathrm{CH}\right)$, $63,7\left(\mathrm{OCH}_{2} \mathrm{CH}_{2} \mathrm{CH}_{2} \mathrm{CH}_{3}\right), 93,6(\mathrm{CH}), 167,0(\mathrm{CONa})$, $168,7\left(\mathrm{COOC}_{4} \mathrm{H}_{9}\right), 199,4\left(\left(\mathrm{CH}_{3}\right)_{2} \mathrm{CHCO}\right)$. Mass spectrum (ESI-TOF), $m / z$ (I rel, \%): $237.1099(62)[\mathrm{M}+\mathrm{H}]^{+}$, $259.0914(47)[\mathrm{M}+\mathrm{Na}]^{+}$. Calculated: for $\mathrm{C}_{11} \mathrm{H}_{18} \mathrm{O}_{4} \mathrm{Na}-$ 237.1097; for $\mathrm{C}_{11} \mathrm{H}_{17} \mathrm{O}_{4} \mathrm{Na}_{2} 259.0917$.

Sodium 1,4-dioxo-4-phenyl-1-ethoxy-2-buten2-olate (1b). Yield $-85 \%, t_{\text {melt }}-156-160{ }^{\circ} \mathrm{C}$. IR spectrum, $v, \mathrm{~cm}^{-1}: 3060 \vee(\mathrm{C}-\mathrm{H}, \mathrm{Ar}), 2979 v_{a s}$ 
$\left(\mathrm{CH}_{3}\right), 2929 v_{\text {as }}\left(\mathrm{CH}_{2}\right), 2871 v_{s}\left(\mathrm{CH}_{2}\right), 1687 v$ $\left(C^{1}=O\right), 1623 \vee\left(C^{4}=O\right), 1575 \vee(C=C), 1505 \vee$ $(\mathrm{C}=\mathrm{C}, \mathrm{Ar}), 1390,1364 \delta\left(\mathrm{CH}_{3}\right), 1231 \vee(\mathrm{C}-\mathrm{O}-\mathrm{C})$, $1097 \delta(\mathrm{CH}, \mathrm{Ar}), 950-753(\mathrm{CH})$. NMR spectrum ${ }^{1} \mathrm{H}$, $\delta$, ppm (DMSO-d $\left.\mathrm{d}_{6}\right): 1.26 \mathrm{t}\left(3 \mathrm{H}, \mathrm{COOCH}_{2} \mathrm{CH}_{3}, J_{\mathrm{HH}}\right.$ $7.4 \mathrm{~Hz}), 4.17 \mathrm{q}\left(2 \mathrm{H}, \mathrm{COOCH}_{2} \mathrm{CH}_{3}, J_{\mathrm{HH}} 7.4 \mathrm{~Hz}\right)$, $6.42 \mathrm{~s}(1 \mathrm{H}, \mathrm{CH}), 7.29-7.51 \mathrm{~m}\left(3 \mathrm{H}, \mathrm{C}^{3} \mathrm{H}, \mathrm{C}^{4} \mathrm{H}\right.$, $\mathrm{C}^{5} \mathrm{H}$ in $\left.\mathrm{C}_{6} \mathrm{H}_{5}\right), 7.82 \mathrm{~d}\left(2 \mathrm{H}, \mathrm{C}^{2}{ }^{1} \mathrm{H}, \mathrm{C}^{6} \mathrm{H}\right.$ in $\left.\mathrm{C}_{6} \mathrm{H}_{5}\right)$. NMR spectrum ${ }^{13} \mathrm{C}, \delta_{\mathrm{c}}$, ppm (DMSO-d $\mathrm{d}_{6}$ ): 14,0 $\left(\mathrm{OCH}_{2} \mathrm{CH}_{3}\right), 60,3\left(\mathrm{OCH}_{2} \mathrm{CH}_{3}\right), 92,0(\mathrm{CH}), 126,4$ $\left(\mathrm{C}^{2^{\prime}}\right.$ and $\mathrm{C}^{6^{\prime}}$ in $\left.\mathrm{C}_{6} \mathrm{H}_{5}\right), 128,1\left(\mathrm{C}^{3^{\prime}}\right.$ and $\mathrm{C}^{5^{\prime}}$ in $\left.\mathrm{C}_{6} \mathrm{H}_{5}\right)$, $129,8\left(\mathrm{C}^{4}\right.$ in $\left.\mathrm{C}_{6} \mathrm{H}_{5}\right), 142,2\left(\mathrm{C}^{1}\right.$ in $\left.\mathrm{C}_{6} \mathrm{H}_{5}\right), 167,2$ (CONa), $170,6 \quad\left(\mathrm{COOC}_{2} \mathrm{H}_{5}\right), \quad 185,4 \quad\left(\mathrm{C}_{6} \mathrm{H}_{5} \mathrm{CO}\right)$. Mass spectrum (ESI-TOF), $\mathrm{m} / \mathrm{z}\left(I_{\text {rel }}, \%\right): 243.0624$ (38) $[\mathrm{M}+\mathrm{H}]^{+}, 265.0443(82)[\mathrm{M}+\mathrm{Na}]^{+}$. Calculated: for $\mathrm{C}_{12} \mathrm{H}_{12} \mathrm{O}_{4} \mathrm{Na}-243.0628$; for $\mathrm{C}_{12} \mathrm{H}_{11} \mathrm{O}_{4} \mathrm{Na}_{2}-$ 265.0447.

Synthesis of bis-(4-alkyl(aryl)-1-oxo-1-alkoxyalkane-2,4-dionato)-metals (II) (2a-2e). General procedure. A solution of $1.0 \mathrm{mmol}(0.18 \mathrm{~g})$ zinc acetate, $1.0 \mathrm{mmol}(0.18 \mathrm{~g})$ of copper acetate or $1.0 \mathrm{mmol}(0.24 \mathrm{~g})$ of nickel chloride hexahydrate in $30-50 \mathrm{ml}$ of water was added with stirring to a solution of $2.0 \mathrm{mmol}$ of sodium 4-alkyl(aryl)-1alkoxy-1,4-dioxo-2-alkenolates (1a or $\mathbf{1 b})$ in $30-50 \mathrm{ml}$ of water for preparation of compounds $2 \mathrm{a}$ and $\mathbf{2 d}, \mathbf{2 b}$ and $2 \mathrm{e}, \mathbf{2 c}$ and $2 \mathrm{f}$, correspondingly. After 30 minutes, the as-formed precipitate was filtered off and recrystallised from ethanol. The yields were not optimised.

Bis-(1-butoxy-5-methyl-1-oxohexane-2,4-dionato) zinc (II) (2a). Yield - $47 \%, t_{\text {melt }}-$ 102-104 ${ }^{\circ} \mathrm{C}$. IR spectrum, $v, \mathrm{CM}^{-1}: 2959 v_{\text {as }}\left(\mathrm{CH}_{3}\right)$, $2933 v_{\text {as }}\left(\mathrm{CH}_{2}\right), 1725 \vee\left(\mathrm{COOC}_{2} \mathrm{H}_{5}\right), 1599 \vee(\mathrm{C}=\mathrm{C})$, $1455 \delta_{a s}\left(\mathrm{CH}_{3}\right), 1267 \vee(\mathrm{C}-\mathrm{O}-\mathrm{C}), 822,781 \delta(\mathrm{CH})$. NMR spectrum ${ }^{1} \mathrm{H}, \delta$, ppm (DMSO-d $\left.)_{6}\right): 0,91 \mathrm{t}(6 \mathrm{H}$, $\left.2 \mathrm{COOCH}_{2} \mathrm{CH}_{3}, J_{\mathrm{HH}} 7,6 \mathrm{~Hz}\right), 0,98 \mathrm{~d}\left(12 \mathrm{H}, 2\left(\mathrm{CH}_{3}\right)_{2} \mathrm{CH}\right.$, $\left.J_{\mathrm{HH}} 7,7 \mathrm{~Hz}\right), 1,35 \mathrm{~m}\left(4 \mathrm{H}, 2 \mathrm{OCH}_{2} \mathrm{CH}_{2} \mathrm{CH}_{2} \mathrm{CH}_{3}\right), 1,59 \mathrm{~m}$ $\left(4 \mathrm{H}, 2 \mathrm{OCH}_{2} \mathrm{CH}_{2} \mathrm{CH}_{2} \mathrm{CH}_{3}\right), 2,40 \mathrm{~m}\left(1 \mathrm{H},\left(\mathrm{CH}_{3}\right)_{2} \mathrm{CH}\right)$, $4,06 \mathrm{t}\left(2 \mathrm{H}, \mathrm{OCH}_{2} \mathrm{CH}_{2} \mathrm{CH}_{2} \mathrm{CH}_{3}, J_{\mathrm{HH}} 7,2 \mathrm{~Hz}\right), 5,64 \mathrm{~s}$ $(2 \mathrm{H}, 2 \mathrm{CH})$. Mass spectrum (ESI-TOF), $\mathrm{m} / \mathrm{z}\left(I_{\text {rel, }} \%\right.$ ): 491.1616 (34) $[\mathrm{M}+\mathrm{H}]^{+}, 508.1887$ (38) $\left[\mathrm{M}+\mathrm{NH}_{4}\right]^{+}$, $513.1436(64)[\mathrm{M}+\mathrm{Na}]^{+}$. Calculated: for $\mathrm{C}_{22} \mathrm{H}_{35} \mathrm{O}_{8} \mathrm{Zn}^{+}-$ 491.1618; for $\mathrm{C}_{22} \mathrm{H}_{38} \mathrm{O}_{8} \mathrm{NZn}^{+}-508.1883$; for $\mathrm{C}_{22} \mathrm{H}_{34} \mathrm{O}_{8} \mathrm{NaZn}^{+}-513.1437$.

Bis-(1-butoxy-5-methyl-1-oxohexane-2,4-dionato) copper (II) (2b). Yield - $38 \%, t_{\text {melt }}-$ 190-192 ${ }^{\circ} \mathrm{C}$. IR spectrum, $v, \mathrm{~cm}^{-1}: 2961 \mathrm{v}_{a s}\left(\mathrm{CH}_{3}\right)$, $2934 v_{\text {as }}\left(\mathrm{CH}_{2}\right), 1722 \vee\left(\mathrm{COOC}_{2} \mathrm{H}_{5}\right), 1582 \vee(\mathrm{C}=\mathrm{C})$, $1456 \delta_{\text {as }}\left(\mathrm{CH}_{3}\right), 1317 \vee(\mathrm{C}-\mathrm{O}-\mathrm{C}), 823,796 \delta(\mathrm{CH})$. Mass spectrum (ESI-TOF), $\mathrm{m} / \mathrm{z}\left(I_{\mathrm{rel}}, \%\right): 512.1443$ (46) $[\mathrm{M}+\mathrm{Na}]^{+}, 528.1182(34)[\mathrm{M}+\mathrm{K}]^{+}$. Calculated: for $\mathrm{C}_{22} \mathrm{H}_{34} \mathrm{O}_{8} \mathrm{NaCu}^{+}$- 512.1442; for $\mathrm{C}_{22} \mathrm{H}_{34} \mathrm{O}_{8} \mathrm{KCu}^{+}$ -528.1181 .

Bis-(1-butoxy-5-methyl-1-oxohexane-2,4-dionato) nickel (II) (2c). Yield $-34 \%, t_{\text {melt }}-98-100$ ${ }^{\circ} \mathrm{C}$. IR spectrum, $v, \mathrm{~cm}^{-1}: 2958 v_{\text {as }}\left(\mathrm{CH}_{3}\right), 2933 v_{\text {as }}$ $\left(\mathrm{CH}_{2}\right), 1724 \vee\left(\mathrm{COOC}_{2} \mathrm{H}_{5}\right), 1598 \vee(\mathrm{C}=\mathrm{C}), 1454 \delta_{a s}$ $\left(\mathrm{CH}_{3}\right), 1269 \vee(\mathrm{C}-\mathrm{O}-\mathrm{C}), 843,777 \delta(\mathrm{CH})$. Mass spectrum (ESI-TOF), $\mathrm{m} / \mathrm{z}\left(I_{\text {rel }} \%\right.$ \%): 485.1682 (65) $[\mathrm{M}+\mathrm{H}]^{+}, 507.1498(32)[\mathrm{M}+\mathrm{Na}]^{+}$. Calculated: for $\mathrm{C}_{22} \mathrm{H}_{35} \mathrm{O}_{8} \mathrm{Ni}^{+}$- 485.1680; for $\mathrm{C}_{22} \mathrm{H}_{34} \mathrm{O}_{8} \mathrm{NaNi}^{+}-$ 507.1499.

Bis-(1-oxo-4-phenyl-1-ethoxybutane-2,4-dionato) zinc (II) (2d). Yield $43 \%, t_{\text {melt }}-130-131^{\circ} \mathrm{C}$. IR spectrum, $v, \mathrm{~cm}^{-1}: 2971 v_{a s}\left(\mathrm{CH}_{3}\right), 1726 v$ $\left(\mathrm{COOS}_{2} \mathrm{H}_{5}\right), 1597,1575 \vee(\mathrm{C}=\mathrm{C}), 1519,1464 v$ $(\mathrm{C}=\mathrm{C}, \mathrm{Ar}), 1429 \delta_{\text {as }}\left(\mathrm{CH}_{3}\right), 1274 \vee(\mathrm{C}-\mathrm{O}-\mathrm{C}), 1170$ $\delta_{\text {planar }}(\mathrm{CH}, \mathrm{Ar}), 770,752 \delta_{\text {non-planar }}(\mathrm{CH}, \mathrm{Ar}) . \mathrm{NMR}$ spectrum ${ }^{1} \mathrm{H}, \delta$, ppm $\left(\right.$ DMSO- $\left.\mathrm{d}_{6}\right): 1,27 \mathrm{t}(6 \mathrm{H}$, $\left.2 \mathrm{COOCH}_{2} \mathrm{CH}_{3}, \quad J_{\mathrm{HH}} \quad 7,4 \mathrm{~Hz}\right), \quad 4,18$ q $(4 \mathrm{H}$, $\left.2 \mathrm{COOCH}_{2} \mathrm{CH}_{3}, J_{\mathrm{HH}} 7,4 \mathrm{~Hz}\right), 6,42 \mathrm{~s}(2 \mathrm{H}, 2 \mathrm{CH})$, 7,24-7,52 $\mathrm{m}\left(6 \mathrm{H}, \mathrm{C}^{3} \mathrm{H}, \mathrm{C}^{4} \mathrm{H}, \mathrm{C}^{5} \mathrm{H}\right.$ in $\left.2 \mathrm{C}_{6} \mathrm{H}_{5}\right), 7,82$ d $\left(4 \mathrm{H}, \mathrm{C}^{2} \mathrm{H}, \mathrm{C}^{6} \mathrm{H}\right.$ in $\left.2 \mathrm{C}_{6} \mathrm{H}_{5}\right)$. Mass spectrum (ESITOF), $\quad \mathrm{m} / \mathrm{z} \quad\left(\mathrm{l}\right.$ rel, \%): 503.0678 (80) $[\mathrm{M}+\mathrm{H}]^{+}$, $520.0945(53)\left[\mathrm{M}+\mathrm{NH}_{4}\right]^{+}, 525.0497(100)[\mathrm{M}+\mathrm{Na}]^{+}$, 541.0235 (22) $[\mathrm{M}+\mathrm{K}]^{+}$. Calculated: for $\mathrm{C}_{24} \mathrm{H}_{23} \mathrm{O}_{8} \mathrm{Zn}^{+}-503.0679$; for $\mathrm{C}_{24} \mathrm{H}_{26} \mathrm{O}_{8} \mathrm{NZn}^{+}-$ 520.0944; for $\mathrm{C}_{24} \mathrm{H}_{22} \mathrm{O}_{8} \mathrm{NaZn}^{+}-525.0498$; for $\mathrm{C}_{24} \mathrm{H}_{22} \mathrm{O}_{8} \mathrm{KZn}^{+}-541.0238$.

Bis-(1-oxo-4-phenyl-1-ethoxybutane-2,4-dionato) copper (II) (2e). Yield - $42 \%, t_{\text {melt }}-$ 125-127 ${ }^{\circ} \mathrm{C}$. IR spectrum, $v, \mathrm{~cm}^{-1}: 2976 v_{\text {as }}\left(\mathrm{CH}_{3}\right)$, $1728 \vee\left(\mathrm{COOC}_{2} \mathrm{H}_{5}\right), 1592 \vee(\mathrm{C}=\mathrm{C}), 1564,1514$, $1456 \vee(\mathrm{C}=\mathrm{C}, \mathrm{Ar}), 1434 \delta_{\text {as }}\left(\mathrm{CH}_{3}\right), 1272 \vee(\mathrm{C}-\mathrm{O}-\mathrm{C})$, $1142 \delta_{\text {planar }}(\mathrm{CH}, \mathrm{Ar}), 769,743 \delta_{\text {non-planar }}(\mathrm{CH}, \mathrm{Ar})$. Mass spectrum (ESI-TOF), $\mathrm{m} / \mathrm{z}\left(\mathrm{I}_{\mathrm{rel}}, \%\right): 502.0685$ (22) $[\mathrm{M}+\mathrm{H}]^{+}, 519.0948(98)\left[\mathrm{M}+\mathrm{NH}_{4}\right]^{+}, 524.0503$ (100) $[\mathrm{M}+\mathrm{Na}]^{+}, 540.0243(48)[\mathrm{M}+\mathrm{K}]^{+}$. Calculated: for $\mathrm{C}_{24} \mathrm{H}_{23} \mathrm{O}_{8} \mathrm{Cu}^{+}-$502.0683; for $\mathrm{C}_{24} \mathrm{H}_{26} \mathrm{O}_{8} \mathrm{NCu}^{+}-$ 519.0949; for $\mathrm{C}_{24} \mathrm{H}_{22} \mathrm{O}_{8} \mathrm{NaCu}^{+}-524.0503$; for $\mathrm{C}_{24} \mathrm{H}_{22} \mathrm{O}_{8} \mathrm{KCu}^{+}-540.0242$.

Bis-(1-oxo-4-phenyl-1-ethoxybutane-2,4-dionato) nickel (II) (2f).Yield - $38 \%, t_{\text {melt }}-$ 140-143 ${ }^{\circ} \mathrm{C}$. IR spectrum, $v, \mathrm{~cm}^{-1}: 2954 v_{\text {as }}\left(\mathrm{CH}_{3}\right)$, $1729 \vee\left(\mathrm{COOC}_{2} \mathrm{H}_{5}\right), 1595,1572 \vee(\mathrm{C}=\mathrm{C}), 1519$, $1456 \vee(\mathrm{C}=\mathrm{C}, \mathrm{Ar}), 1422 \delta_{\text {as }}\left(\mathrm{CH}_{3}\right), 1269 \vee(\mathrm{C}-\mathrm{O}-\mathrm{C})$, $1146 \delta_{\text {planar }}(\mathrm{CH}, \mathrm{Ar}), 771,745 \delta_{\text {non-planar }}(\mathrm{CH}, \mathrm{Ar})$. Mass spectrum (ESI-TOF), $\mathrm{m} / \mathrm{z}\left(I_{\mathrm{rel}}, \%\right): 497.0745$ (56) $[\mathrm{M}+\mathrm{H}]^{+}, 519.0561(42)[\mathrm{M}+\mathrm{Na}]^{+}$. Calculated: for $\mathrm{C}_{24} \mathrm{H}_{23} \mathrm{O}_{8} \mathrm{Ni}^{+}-497.0741$; for $\mathrm{C}_{24} \mathrm{H}_{22} \mathrm{O}_{8} \mathrm{NaNi}^{+}{ }_{-}$ 519.0560 .

IR spectra of compounds $\mathbf{1 a}, \mathbf{1 b}$ were recorded on a Bruker Alpha FTIR spectrometer; ATR mode, ZnSe crystal IR spectra of compounds 2a-2e were recorded on a Vertex 70 IR Fourier spectrometer (Bruker, Germany): range $400-4000 \mathrm{~cm}^{-1}$, resolution $-2 \mathrm{~cm}^{-1}$, number of scans of the background and sample - 32, ATR mode, diamond crystal. NMR spectra ${ }^{1} \mathrm{H}$ of the compounds $\mathbf{1 a}, \mathbf{1 b}, \mathbf{2 a}$ and $\mathbf{2 d}$ and $\mathrm{NMR}{ }^{13} \mathrm{C}$ of the compounds $\mathbf{1 a}$ and $\mathbf{1 b}$ in DMSO- $d_{6}$ were obtained using NMR Fourier spectrometer Bruker AVANCE II (400 MHz), internal standard TMS. Mass spectra of the compounds 1, 2 were recorded on a quadrupole-time-of-flight ultra-highresolution mass spectrometer Orbitrap Elite, MicroTof Bruker Daltonics. Positive ions were de- 
tected in the electrospray ionisation (ESI) mode. Samples dissolved in DMSO diluted with acetonitrile or methanol were injected with a syringe pump at a flow rate of $240 \mu \mathrm{l} / \mathrm{h}$.

The individuality of the obtained substances was confirmed by TLC on Silufol UV-254 plates in the benzene-ether-acetone (10:9:1) system or acetone-hexane (2:3) system; the chromatograms were stained using iodine vapour. The initial reagents were purified by distillation before use.

The optimisation of the geometric parameters of the equilibrium states of sodium oxoenolate and metal complexes was carried out using the following two methods: density functional theory (DFT) and self-consistent field (SCF). When calculating using the SCF method, the aug-cc-pVDZ basis was used, while the DFT method used the PBE/DZP approximation. Accounting for solvents was carried out according to the PCM model, in the case of compounds $\mathbf{1 a}, \mathbf{1} \mathbf{b}$ - benzene and water, for compounds $\mathbf{2 a - 2 f}-$ water. The relative formation energies of the structures 2a-2f were calculated using the following equations

$$
\Delta G^{\circ}(E)=G^{\circ}(E) \Sigma_{\mathrm{pr}}-G^{\circ}(E) \Sigma_{\text {reag }}[17] .
$$

The calculations were performed in the FireFly 8.1 software package.

\section{RESULTS AND DISCUSSION}

The condensation of alkyl(aryl)methyl-ketones(3-methylbutanone-2 and acetophenone) with dialkyl oxalates (diethyl oxalate and di- $n$-butyloxalate) in the presence of sodium or sodium hydride in benzene or toluene at a ratio of the starting reagents 1:1:1 yielded sodium 1-alkoxy-1,4dioxo-2-alkenolates (1) (Fig. 1).

New bis-(4-alkyl(aryl)-1-oxo-1-alkoxyalkane 2,4-dionato)-metals (II) (2) were synthesised by complex formation of sodium oxoenolates (1) with salts of zinc (II), copper (II) and nickel (II) in an aqueous medium with the initial ratio of reagents of 2:1 (Fig. 2).

The structure of the obtained sodium oxoenolates (1) and metal (II) complexes (2) based on them was confirmed by means of IR, $\mathrm{NMR}^{1} \mathrm{H}-$, $\mathrm{NMR}^{13} \mathrm{H}$-spectroscopy, as well as mass spectrometry ${ }^{1,2}$

$\Delta G^{\circ}(E)=G^{\circ}(E)(\mathrm{MeX})-G^{\circ}(E)\left(\mathrm{Me}^{2+}\right)+G^{\circ}(E)\left(2 X^{\circ}\right) ;$

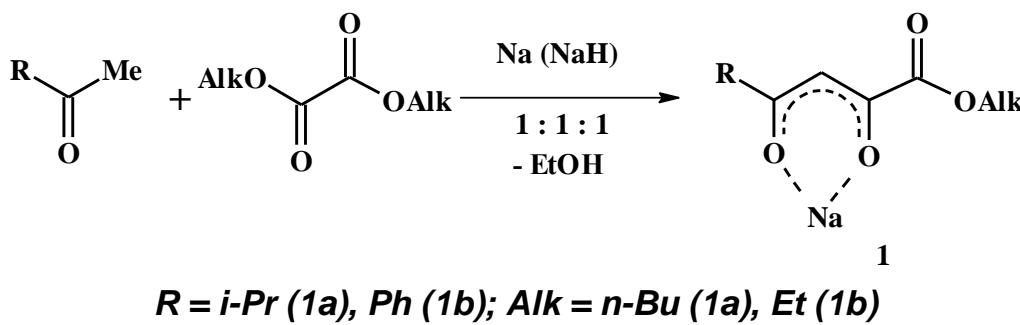

$$
R=i-\operatorname{Pr}(1 a), P h \text { (1b); Alk = n-Bu (1a), Et (1b) }
$$

Fig. 1. Scheme of the synthesis of 1-alkoxy-1,4-dioxo-2-sodium alkenolates (1)

Рuc. 1. Схема синтеза 1-алкокси-1,4-диоксо-2-алкенолятов натрия (1)<smiles>[R]c1cc(C(=O)O[Na])no1</smiles><smiles>[R]C(=CC(=O)C(=O)OC)O[Y14]1oc([R])cc1C(=O)O[Na]</smiles>

2

$$
\begin{gathered}
R=i-\operatorname{Pr}(2 a, 2 b, 2 c), \operatorname{Ph}(2 d, 2 e, 2 f) ; A l k=n-B u(2 a, 2 b, 2 c), E t(2 d, 2 e, 2 f) \\
M e t=Z n(I I)(2 a, d), C u(I I)(2 b, e), N i(I I)(2 c, f)
\end{gathered}
$$

Fig. 2. Scheme of synthesis of bis-[4-alkyl(aryl)-1-oxo-1-alkoxyalkane-2,4-dionato] metals (II) (2)

Puc. 2. Схема синтеза бис-(4-алкил(арил)-1-оксо-1-алкоксиалкан-2,4-дионато)металлов(II) (2)

\footnotetext{
${ }^{7}$ Pretsch E, Bühlmann P, Affolter C. Structure Determination of Organic Compounds. Tables of spectral data (translated from English by B.N. Tarasevich). Moscow: Mir; BINOM. Laboratorya Znanii, 2006. 438 p.

${ }^{2}$ Silverstein R, Webster F, Kiemle D. Spectrometric identification of organic compounds (translated from English by N.M. Sergeev, B.N. Tarasevich). Moscow: BINOM. Laboratorya Znanii, 2012. 557 p.
} 
IR spectra of solid samples of sodium 1-alkoxy-1,4-dioxo-2-alkenolates (1) and bis-(4alkyl(aryl)-1-oxo-1-alkoxyalkane-2,4-dionato) metals (II) (2) are characterised by the presence of a bright stretching band of the ester carbonyl group in the region of 1698-1687 $\mathrm{cm}^{-1}$ (for compounds 1a and $\mathbf{1 b}$ ) and 172-1722 $\mathrm{cm}^{-1}$ (for compounds 2a-2f). The bands in the region of $1597-1456 \mathrm{~cm}^{-1}$ are due to vibrations of monosubstituted aromatic rings (for compounds $\mathbf{1 b}$ and $\mathbf{2 d - 2 f}$ ). The highfrequency ether band arising due to vibrations of the C-O-C fragment appears in the region of 1267-1231 $\mathrm{cm}^{-1}$ (for compounds $\mathbf{1 a}$ and $\mathbf{1 b}$ ) and $1317-1267 \mathrm{~cm}^{-1}$ (for compounds 2a-2f).

In the NMR spectra of ${ }^{1} \mathrm{H}$ sodium oxoenolates (1a and $\mathbf{1 b}$ ) and zinc complexes (2a and $\mathbf{2 d}$ ) recorded in DMSO- $\mathrm{d}_{6}$, the characteristic ethoxy fragments signals are observed for $\mathbf{1 b}$ and $\mathbf{2 d}$ ) and n-butoxy fragments signals (for compounds $1 \mathbf{a}$ and 2a). Methine protons are identified by singlet signals in the region of 5.65-6.42 ppm. Proton signals of the monosubstituted aromatic rings for compounds $\mathbf{1 b}$ and $\mathbf{2 d}$ with phenyl fragments were recorded in the range 7.24-7.82 ppm.

The NMR spectra of ${ }^{13} \mathrm{C}$ sodium oxoenolates (1a and $\mathbf{1 b}$ ) recorded in DMSO- $d_{6}$, contain signals of alkyl carbon atoms in the range 13.5-30.1 ppm. The signals of aromatic carbon atoms (for compound 1b) were recorded in the region of 126.4-142.2 ppm. Carbon atoms of carbonyl groups of ester fragments were detected at 168.7 (for $n$-butoxycarbonyl group of compound 1a) and 170.6 (for ethoxycarbonyl group of compound 1b).

In the mass spectra of synthesised compounds recorded in the electrospray mode, signals of protonated and cationised molecules are observed $[\mathrm{M}+\mathrm{H}]^{+},\left[\mathrm{M}+\mathrm{NH}_{4}\right]^{+},[\mathrm{M}+\mathrm{Na}]^{+}[\mathrm{M}+\mathrm{K}]^{+}$.

In order to study the stability of the synthesised compounds, quantum-chemical calculations of their formation energies were carried out (Table 1). The calculations demon-strate the best convergence under the HF / aug-cc-pVDZ approximation. The solvation effects were considered only in the PBE / DZP approximation; in view of the complexity of the calculation, the solvation correction for the aug-cc-pVDZ basis was not considered in the SCF method. According to the obtained data, copper complexes have the greatest stability in the gas phase out of all the complexes tested. In general, according to the relative values of the formation energies, all compounds are stable, and metal complexes (2) are characterised by greater stability compared to sodium oxoenolates (1).

The values of the theoretically calculated dissociation constants of the obtained compounds are provided in Table 2. The obtained values indicate that zinc complexes $(\mathbf{2} \mathbf{a}, \mathbf{2} \mathbf{d})$ possess the highest electrolytic dissociation capacity of all obtained metal complexes, while the compounds $\mathbf{1 a}, \mathbf{1 b}$ are relatively similar in terms of electrolyte strength.

Table 1

Absolute $\left(E^{0}, G^{0}\right)$ and relative $(\Delta E, \Delta G)$ formation energies of compounds $1 a, 1 b, 2 a-2 f$

Таблица 1

Абсолютные $\left(E^{0}, G^{0}\right)$ и относительные $(\Delta E, \Delta G)$ энергии образования соединений $1 \mathrm{a}, 1 \mathrm{~b}, 2 \mathrm{a}-2 \mathrm{f}$

\begin{tabular}{|c|c|c|c|c|c|c|}
\hline \multirow{2}{*}{ Compound } & \multicolumn{2}{|c|}{$\mathrm{HF} / \mathrm{aug}-\mathrm{cc}-\mathrm{pVDZ}$} & \multicolumn{2}{c|}{$\mathrm{PBE} / \mathrm{DZP}$} & \multicolumn{2}{c|}{$\mathrm{PBE} / \mathrm{DZP}+\mathrm{PCM}$} \\
\cline { 2 - 7 } & $\mathrm{E}^{0}$, Hartree & $\Delta \mathrm{E}, \mathrm{kJ} / \mathrm{mol}$ & $\mathrm{G}^{0}, \mathrm{Hartree}$ & $\Delta \mathrm{E}, \mathrm{kJ} / \mathrm{mol}$ & $\mathrm{G}^{0}, \mathrm{Hartree}$ & $\Delta \mathrm{E}, \mathrm{kJ} / \mathrm{mol}$ \\
\hline 1a & $-887,923168$ & $-143,3$ & $-891,566532$ & $-161,5$ & $-891,584457$ & $-137,6$ \\
1b & $-922,301360$ & $-145,2$ & $-926,104389$ & $-157,3$ & $-926,125552$ & $-139,0$ \\
2a & $-3229,962850$ & $-1315,8$ & $-3237,721356$ & $-1435,8$ & $-3237,765320$ & $-79,6$ \\
2b & $-3091,107386$ & $-1354,0$ & $-3098,915975$ & $-1556,8$ & $-3098,947774$ & $-922,5$ \\
2c & $-2959,021762$ & $-1270,8$ & $-2966,768176$ & $-1509,1$ & $-2966,787241$ & $-384,2$ \\
2d & $-3298,717676$ & $-1311,7$ & $-3306,801958$ & $-1448,6$ & $-3306,847853$ & $-80,5$ \\
2e & $-3159,861688$ & $-1348,6$ & $-3167,994962$ & $-1565,4$ & $-3168,030201$ & $-923,1$ \\
2f & $-3027,776747$ & $-1267,1$ & $-3035,849309$ & $-1523,3$ & $-3035,872814$ & $-393,1$ \\
\hline
\end{tabular}

Table 2

Dissociation constants of compounds

$1 a, 1 b, 2 a, 2 c, 2 d, 2 f$

Таблица 2

Константы диссоциации соединений

$1 a, 1 b, 2 a, 2 c, 2 d, 2 f$

\begin{tabular}{|c|c|c|}
\hline \multirow{2}{*}{ Compound } & \multicolumn{2}{|c|}{ PBE / DZP + PCM } \\
\cline { 2 - 3 } & Stage I & Stage II \\
\hline 1a & $9,5 \cdot 10^{-39}$ & - \\
1b & $4,5 \cdot 10^{-38}$ & - \\
2a & $1,7 \cdot 10^{-42}$ & $1,4 \cdot 10^{-28}$ \\
2c & $7,3 \cdot 10^{-96}$ & $6,0 \cdot 10^{-82}$ \\
2d & $8,0 \cdot 10^{-41}$ & $7,9 \cdot 10^{-28}$ \\
2f & $1,4 \cdot 10^{-95}$ & $1,4 \cdot 10^{-82}$ \\
\hline
\end{tabular}




\section{CONCLUSIONS}

During the study, potentially valuable sodium 1-alkoxy-1,4-dioxo-2-alkenolates and complexes of zinc (II), copper (II) and nickel (II) with carbonylcontaining ligands were successfully synthesised.
Their structure was established using IR, NMR ${ }^{1} \mathrm{H}$-, NMR ${ }^{13} \mathrm{C}$-spectroscopy and high-resolution mass spectrometry methods. Quantum-chemical calculations of the formation energies and dissociation constants were carried out.
1. Popov LD, Morozov AN, Shcherbakov IN, Tupolova YuP, Lukov VV, Kogan VA. Metal complexes with polyfunctional ligands based of bis(hydrazones) of dicarbonyl compounds. Russian Chemical Reviews. 2009;78(7):643-658. https://doi.org/10.1070/RC2009v078n07ABEH003 890

2. Levchenkov SI, Shcherbakov IN, Popov LD, Lyubchenko SN, Tsaturyan AA, Beloborodov SS, et al. Transition metal complexes with 2,6-di-tert-butyl-p-quinone 1'-phthalazinylhydrazone. Russian Journal of General Chemistry. 2013;83(10):1928-1936. https://doi.org/10.1134/ S1070363213100216

3. Burlov AS, Zaichenko SB, Popov LD, Vlasenko VG, Borodkin GS, Makarova NI, et al. Synthesis, Structure, and spectral properties of 3,5-di-tert-butyl-1,2-benzoquinone 3-hydroxynaphthoylhydrazone and Its complexes with $\mathrm{Zn}(\mathrm{II}), \mathrm{Cd}(\mathrm{II}), \mathrm{Ni}(\mathrm{II}), \mathrm{Co}(\mathrm{II})$. Russian Journal of General Chemistry. 2019;89(4):727-735. https:// doi.org/10.1134/S1070363219040157

4. Popov LD, Shcherbakov IN, Tupolova YP, Etmetchenko LN, Kogan VA, Levchenkov SI, et al. Copper(II) complexes with $\mathrm{N}$-(phenyl)alkylthiosemicarbazones of 3,5-dichloro- and 3,5-diiodosalicylic aldehydes. Russian Journal of General Chemistry. 2016;86(2):344-348. https://doi.org/ $10.1134 / \mathrm{S} 1070363216020249$

5. Shcherbakov KV, Burgart YaV, Saloutin VI. Metal complexes based on functionalized 4-hydroxypolyfluorocoumarins. Russian Journal of Organic Chemistry. 2014;50(6):815-821. https:// doi.org/10.1134/S1070428014060104

6. Melkozerov SA, Pervova IG, Lipunov IN, Dvoskin EA, Lipunova GN, Barachevskii VA. Synthesis and photoluminescence properties of zinc(II) complexes with salicylaldehyde hetarylhydrazones. Russian Journal of General Chemistry. 2013;83(4):646-651. https://doi.org/10.11 34/S1070363213040063

7. Kudyakova YuS, Goryaeva MV, Burgart YaV, Saloutin VI. Asymmetric azomethine ligands based on 2-[(2-aminophenyl)aminomethylidene]-3-oxo-3-polyfluoroalkylpropionates and aldehydes. Russian Chemical Bulletin. 2010;59(9):1753-1760. https://doi.org/10.1007/ s11172-010-0308-8

8. Metelitsa AV, Burlov AS, Borodkina IG, Bren VA, Garnovskii AD, Minkin VI, et al. Luminescent complexes with ligands containing $\mathrm{C}=\mathrm{N}$ bond. Russian Journal of Coordination

\section{REFERENCE}

Chemistry. 2006;32(12):858-868. https://doi.org/ 10.1134/S1070328406120025

9. Blokhin YI, Lyubimov IA, Bagautdinov AM, Abramov IA, Khotina IA, Karnoukhova VA. Copper(I) complexes with phenylphosphonous acid diamide. Russian Journal of Coordination Chemistry. 2016;42(6):372-377. https://doi.org/ 10.1134/S1070328416060014

10. Yang T, Niu F, Li LX, Xia ZN, Zhang Y, You ZL. Synthesis, characterization, crystal structures, and antimicrobial activity of cobalt(II) and iron(III) complexes derived from $\mathrm{n}$-(2hydroxybenzylidene)-3-methylbenzohydrazide. Russian Journal of Coordination Chemistry. 2016;42(6): 402-409. https://doi.org/10.1134/S10 70328416050109

11. Kuvshinova EM, Bykova MA, Vershinina IA, Gornukhina OV, Lyubimova TV, Semeykin AS. Synthesis and coordination properties of cobalt complexes of 5-phenyl-2,3,7,8,12,18-hexamethyl13,17-diethylporphine and its nitrosubstituted in organic solvents. Izvestiya Vysshikh Uchebnykh Zavedenii. Khimiya $i$ Khimicheskaya Tekhnologiya = Russian Journal of Chemistry and Chemical Technology. 2018;61(7):44-49. (in Russian) https:// doi.org/ 10.6060/ivkkt.20186107.5843

12. Kudayarova T.V., Tyutina M.A., Danilova E.A. Complexes of izothiadiazole-containing bromonitrosubstituted three units product with d-metals (Ni, Co, Zn). Izvestiya Vysshikh Uchebnykh Zavedenii. Khimiya i Khimicheskaya Tekhnologiya = Russian Journal of Chemistry and Chemical Technology. 2018;61(12):68-73. https:// doi.org/10.6060/ivkkt.20186112.5799

13. Chizhova NV, Ivanova YuB, Mamardashvili NZ, Rusanov Al, Khrushkova YV. Synthesis and spectral and fluorescent properties of metal complexes of octakis(4-flurophenyl)tetraazaporphyrins. Russian Journal of Organic Chemistry. 2019; 55(5):655-661. https://doi.org/10.1134/S107042801905 0129

14. Seifullina II, Martsinko EÉ, Chebanenko EA, Gridina TL, Mudrik LM, Fedchuk AS. Antiviral properties of the new coordination compound silver bis(citrato)germanate. Pharmaceutical Chemistry Journal. 2019;53(4):318321. https://doi.org/10.1007/s11094-019-01999-w

15. Mustafina AR, Skripacheva VV, Konovalov Al. Outer-sphere association of calixarenes and other macrocyclic ligands with metal complexes as the basis for the design of molecular devices. Russian Chemical Reviews. 
2007; 76(10): 917-930. http://dx.doi.org/10.1070/ RC2007v076n10ABEH003727

16. Amerkhanova ShK, Nurkenov OA, Uali AS, Satpaeva ZhB, Abdiken FS. And complex formation ability of n-2-(2-ydroxyben-zoyl)hydrazinocarbonotioilbenzamide towards to La3+, $\mathrm{Y} 3+$, $\mathrm{Nd} 3+$ ions in binary mixture "water-1,4-dioxane". Izvestiya Vuzov. Prikladnaya Khimiya i Biotekhnologiya $=$ Proceedings of Universities. Applied Che- mistry and Biotechnology. 2016;6(4):9-14. (In Russian) https://doi.org/10.21285/2227-2925- 2016-6-4-914

17. Peshkov SA, Khursan SL. Complexation of the $\mathrm{Zn}, \mathrm{Co}, \mathrm{Cd}$, and $\mathrm{Pb}$ ions by metallothioneins: A QM/MM simulation. Computational and Theoretical Chemistry. 2017;1106:1-6. http:// doi.org/10.1016/j.comptc. 2017.02.029

\section{БИЛИОГРАФИЧЕСКИЙ СПИСОК}

1. Popov L.D., Morozov A.N., Shcherbakov I.N., Tupolova Yu.P., Lukov V.V., Kogan V.A. Metal complexes with polyfunctional ligands based of bis(hydrazones) of dicarbonyl compounds // Russian Chemical Reviews. 2009. Vol. 78. Issue 7. P. 643-658. https://doi.org/ 10.1070/RC2009v078n07ABEH003890

2. Levchenkov S.I., Shcherbakov I.N., Popov L.D., Lyubchenko S.N., Tsaturyan A.A., Beloborodov S.S., et al. Transition metal comple-xes with 2,6-di-tert-butyl-p-quinone 1'-phthalazinylhydrazone // Russian Journal of General Chemistry. 2013. Vol. 83. Issue 10. P. 1928-1936. https://doi.org/10.1134/S10703632 13100216

3. Burlov A.S., Zaichenko S.B., Popov L.D., Vlasenko V.G., Borodkin G.S., Makarova N.I., et al. Synthesis, structure, and spectral properties of 3,5-di-tert-butyl-1,2-benzoquinone 3-hydroxynaphthoylhydrazone and Its complexes with $\mathrm{Zn}(\mathrm{II}), \mathrm{Cd}(\mathrm{II}), \mathrm{Ni}(\mathrm{II}), \mathrm{Co}(\mathrm{II})$ // Russian Journal of General Chemistry. 2019. Vol. 89. Issue 4. P. 727735. https://doi.org/10.1134/S1070363219040157

4. Popov L.D., Shcherbakov I.N., Tupolova Y.P., Etmetchenko L.N., Kogan V.A., Levchenkov S.I., et al. Copper(II) complexes with $\mathrm{N}$-(phenyl)alkylthiosemicarbazones of 3,5-dichlo-ro- and 3,5-diiodosalicylic aldehydes // Russian Journal of General Chemistry. 2016. Vol. 86. Issue 2. P. 344-348. https:// doi.org/10.1134/ S1070363216020249

5. Shcherbakov K.V., Burgart Ya.V., Saloutin V.I. Metal complexes based on functionalized 4-hydroxypolyfluorocoumarins // Russian Journal of Organic Chemistry. 2014. Vol. 50. Issue 6. P. 815-821. https://doi.org/ $10.1134 / S 1070428014060104$

6. Melkozerov S.A., Pervova I.G., Lipunov I.N., Dvoskin E.A., Lipunova G.N., Barachevskii V.A. Synthesis and photoluminescence properties of zinc(II) complexes with salicylaldehyde hetarylhydrazones // Russian Journal of General Chemistry. 2013. Vol. 83. Issue 4. P. 646-651. https://doi.org/10.1134/ S1070363213040063

7. Kudyakova Yu.S., Goryaeva M.V., Burgart Ya.V., Saloutin V.I. Asymmetric azomethine ligands based on 2-[(2-aminophenyl)aminomethylidene]-3-oxo-3-polyfluoroalkylpropionates and aldehydes // Russian Chemical Bulletin. 2010.
Vol. 59. Issue 9. P. 1753-1760. https://doi.org/ 10.1007/s11172-010-0308-8

8. Metelitsa A.V., Burlov A.S., Borodkina I.G., Bren V.A., Garnovskii A.D., Minkin V.I., et al. Luminescent complexes with ligands containing $\mathrm{C}=\mathrm{N}$ bond // Russian Journal of Coordination Chemistry. 2006. Vol. 32. Issue 12. P. 858-868. https://doi.org/10.1134/S1070328406120025

9. Blokhin Y.I., Lyubimov I.A., Bagautdinov A.M., Abramov I.A., Khotina I.A., Karnoukhova V.A. Copper(I) complexes with phenylphosphonous acid diamide // Russian Journal of Coordination Chemistry. 2016. Vol. 42. Issue 6. P. 372-377. https://doi.org/10.1134/S10703284160 60014

10. Yang T., Niu F., Li L.X., Xia Z.N., Zhang Y., You Z.L. Synthesis, characterization, crystal structures, and antimicrobial activity of cobalt(II) and iron(III) complexes derived from n-(2-hydroxybenzylidene)-3-methylbenzohydrazide // Russian Journal of Coordination Chemistry. 2016. Vol. 42. Issue 6. P. 402-409. https://doi.org/10.1134/S107032841 6050109

11. Кувшинова Е.М., Быкова М.А., Вершинина И.А., Горнухина О.В., Любимова Т.В., Семейкин А.С. Синтез и координационные свойства кобальтовых комплексов 5-фенил2,3,7,8,12,18-гексаметил-13,17-диэтилпорфина и его нитрозамещенных в органических растворителях // Известия высших учебных заведений. Серия: Химия и химическая технология. 2018. T. 61. N 7. C. 44-49. https:

//doi.org/10.6060/ ivkkt.20186107.5843

12. Kudayarova T.V., Tyutina M.A., Danilova E.A. Complexes of izothiadiazole-containing bromonitrosubstituted three units product with d-metals (Ni, Co, Zn) // Известия высших учебных заведений. Серия: Химия и химическая технология. 2018. Т. 61. N 12. С. 68-73. https:// doi.org/10.6060/ivkkt.20186112. 5799

13. Chizhova N.V., Ivanova Yu.B., Mamardashvili N.Z., Rusanov A.I., Khrushkova Y.V. Synthesis and spectral and fluorescent properties of metal complexes of octakis(4flurophenyl)tetraazaporphyrins // Russian Journal of Organic Chemistry. 2019. Vol. 55. Issue 5. P. 655-661. https://doi.org/10.1134/S10704280 19050129 
14. Seifullina I.I., Martsinko E.É., Chebanenko E.A., Gridina T.L., Mudrik L.M., Fedchuk A.S. Antiviral properties of the new coordination compound silver bis(citrato)germanate // Pharmaceutical Chemistry Journal. 2019. Vol. 53. Issue 4. P. 318-321. https://doi.org/ 10.1007/s11094-019-01999-w

15. Mustafina A.R., Skripacheva V.V., Konovalov A.I. Outer-sphere association of calixarenes and other macrocyclic ligands with metal complexes as the basis for the design of molecular devices // Russian Chemical Reviews. 2007. Vol. 76. Issue 10. P. 917-930. http://doi.org/ 10.1070/RC2007v076n10ABEH003727

\section{Критерии авторства}

Elena A. Kunavina, Sergey A. Peshkov, Aybek Yu. Iskandarov carried out the experimental work. The authors on the basis of the results summarized the material and wrote the manuscript. All authors have equal author's rights and bear equal responsibility for plagiarism.

\section{Conflict interests}

The authors declare no conflict of interests regarding the publication of this article.

The final manuscript has been read and approved by all the co-authors.

\section{INFORMATION ABOUT THE AUTHORS}

Elena A. Kunavina,

Cand. Sci. (Chemistry), Associate Professor, Orenburg State University,

13, Pobedy Ave., Orenburg, 460018,

Russian Federation,

e-mail: kea20072007@yandex.ru

Sergey A. Peshkov,

Cand. Sci. (Chemistry), Associate Professor, Orenburg State University,

13, Pobedy Ave., Orenburg, 460018,

Russian Federation,

e-mail: darvin156@mail.ru

\author{
Aybek Yu. Iskandarov, \\ Associate Professor, \\ Department of Chemistry and Methodology \\ of Teaching Chemistry, \\ Tashkent State Pedagogical University, \\ 27, Bunyodkor Ave., Tashkent, 100183, \\ Uzbekistan, \\ e-mail: oybekiskandarov@mail.ru
}

16. Амерханова Ш.К., Нуркенов О.А., Уали А.С., Сатпаева Ж.Б., Абдикен Ф.С. Синтез и комплексообразующая способность n-2-(2-гидроксибензоил)-гидразинокарбонотиоилбензамида (II) по отношению к ионам $\mathrm{La}^{3+}, \mathrm{Y}^{3+}, \mathrm{Nd}^{3+}$ в бинарной смеси «вода-1,4диоксан» // Известия вузов. Прикладная химия и биотехнология. 2016. Т. 6. N 4. С. 9-14. https://doi.org/10.21285/2227-2925-2016-6-4-9-14

17. Peshkov S.A., Khursan S.L. Complexation of the $\mathrm{Zn}, \mathrm{Co}, \mathrm{Cd}$, and $\mathrm{Pb}$ ions by metallothioneins: A QM/MM simulation // Computational and Theoretical Chemistry. 2017. Vol. 1106. P. 1-6. http: //doi.org/10.1016/ j.comptc.2017.02.029

\section{Contribution}

Кунавина Е.А., Пешков С.А., Искандаров А.Ю. выполнили экспериментальную работу. Авторы совместно обобщили результаты, написали рукопись, имеют на статью равные авторские права и несут равную ответственность за плагиат.

\section{Конфликт интересов}

Авторы заявляют об отсутствии конфрликта интересов.

Все авторы прочитали и одобрили окончательный вариант рукописи.

\section{СВЕДЕНИЯ ОБ АВТОРАХ}

\section{Кунавина Елена Александровна,} к.Х.Н., доцент,

Оренбургский государственный университет, 460018, г. Оренбург, пр-т Победы, 13,

Российская Федерация, e-mail: kea20072007@yandex.ru

\section{Пешков Сергей Алексеевич, к.Х.Н., доцент, Оренбургский государственный университет, 460018, г. Оренбург, пр-т Победы, 13, Российская Федерация, e-mail: darvin156@mail.ru}

\footnotetext{
Искандаров Айбек Юлдашевич, доцент, заведующий кафедрой химии и методики ее преподавания, Ташкентский государственный педагогический университет, 100183, г. Ташкент, пр-т Бунедкор, 27, Узбекистан, e-mail: oybekiskandarov@mail.ru
} 